


biblio.ugent.be

The UGent Institutional Repository is the electronic archiving and dissemination platform for all UGent research publications. Ghent University has implemented a mandate stipulating that all academic publications of UGent researchers should be deposited and archived in this repository. Except for items where current copyright restrictions apply, these papers are available in Open Access.

This item is the archived peer-reviewed author-version of:

Searching for the Mecca of finance: Islamic financial services and the world city network Bassens, D., Derudder, B. \& Witlox, F.

In: Area, 42 (1), 35-46, 2010.

doi: $10.1111 / \mathrm{j} .1475-4762.2009 .00894 . x$

To refer to or to cite this work, please use the citation to the published version:

Bassens, D., Derudder, B. \& Witlox, F. (2010). Searching for the Mecca of finance: Islamic financial services and the world city network. Area 42 (1), 35-46. doi: 10.1111/j.14754762.2009.00894.x 


\title{
Searching for the Mecca of finance: Islamic financial services and the world city network
}

\author{
David Bassens, Research Assistant of the Research Foundation - Flanders, Ghent University, \\ Geography Department, Krijgslaan 281 S8, 9000 Ghent, Belgium, e-mail: \\ David.Bassens@UGent.be
}

Ben Derudder, Professor of Human Geography, Ghent University, Geography Department, Krijgslaan 281 S8, 9000 Ghent, Belgium, e-mail: Ben.Derudder@UGent.be

Frank Witlox, Professor of Economic Geography, Ghent University, Geography Department, Krijgslaan 281 S8, 9000 Ghent, Belgium, e-mail: Frank.Witlox@UGent.be

\begin{abstract}
This paper presents an analysis of the geography of the booming 'Islamic financial services' (IFS) sector, which provides a host of financial services based on Islamic religious grounds. The relevance of such an analysis is discussed against the conceptual backdrop of the world city network literature. It is argued that a focus on the globalization of the IFS sector may provide an alternative to hegemonic geographical imaginations of world city-formation through its focus on other forms of globalizing economic processes and regions that do not commonly feature in this literature (the Middle East and North Africa in particular). Based on information on the location strategies of 28 leading IFS firms in 64 cities across the world, we analyze different features of this decentred global urban geography. Manama is hereby identified as the Mecca of the IFS sector. Other major MENA cities such as Tehran and Dubai follow suit, but also more traditional financial centres such as London and Paris are well-connected.
\end{abstract}

Keywords: MENA region, Islamic financial services, world city network, GCC, international financial centers, ethic banking 


\section{Introduction}

This paper presents an analysis of the geography of the booming 'Islamic financial services' (IFS) sector, which provides banking, financial and insurance services based on Islamic religious grounds. The origins of the IFS sector can be traced back to the 1973 energy crisis, after which some of the oil-producing states in the Middle East and North Africa (MENA) quickly accumulated enormous amounts of capital. As is well-known, these excess profits were partly invested through 'conventional' banks throughout the world (but mainly headquartered in Europe and the United States), but at the same time it laid the basis for a number of new financial institutions and instruments within the region.

In the past few years, IFS have also been introduced beyond the MENA. This introduction occurred either through product differentiation within 'conventional' (often Western) banks or through (mainly Middle Eastern) Islamic banks that have 'gone global'. In the latter case, these firms established foreign branches across the world, an evolution that is largely similar to the globalization strategies of the more commonly studied Western banks and business service firms. In this paper, we examine the geography of these globalizing IFS firms with the aim to present an example of a 'decentred' urban geography of contemporary globalization.

To this end, we draw on the methodology developed by Peter Taylor and some of his colleagues of the Globalization and World Cities (GaWC, http://www.lboro.ac.uk/gawc) research group and network. Based on the GaWC methodology, we collected data on the branch locations of the topranked IFS firms, and use this information to disclose the main features of the urban geography of this sector. These results are in turn used to shed some light on the conceptual and empirical relations between this IFS-based city network and earlier research on the world city network (WCN) in general and international financial centres in particular. In this respect, the objective of this paper is largely similar to that of Brown et al. (2002). In the latter article, the authors complement recent research on globalized urbanization through an analysis of how cities in Central America, a region 'beyond' the commonly identified WCN obtain their global business services, and are thereby linked to the wider global economy. It can be said that a focus on IFS results in a related analysis for the MENA region, in that MENA cities that do not commonly feature in conventional world city rankings are major nodes in the networks of such firms (e.g., Manama, Dubai, Abu Dhabi, Tehran and Beirut). As a consequence, this paper can be thought of as an analysis of how the MENA region is integrated in the WCN through its provision of a specific type of business services.

The remainder of this paper is organized as follows. In the next section, we discuss how a global urban analysis of the IFS sector may help rectifying a number of limitations of previous WCN research. After a brief overview of the major features of IFS, we briefly outline the GaWC methodology that has guided our data collection. Based on information on the location strategies of 28 major transnational IFS firms in 64 cities across the world, we then provide a detailed assessment of the urban geography of the globalizing IFS sector, after which the paper is concluded with a discussion of the main consequences and implications of this analysis.

\section{Rationale: IFS within the world city network}

World cities and corporate services

Although relatively young, the literature on world city-formation is both broad and extensive. The emergence of this research domain is most commonly traced back to two interrelated papers by 
Friedmann and Wolff (1982) and especially Friedmann (1986) ${ }^{1}$. Both texts framed the rise of world cities in the context of a major geographical transformation of the world economy. This restructuring, most commonly referred to as the 'New International Division of Labor', was basically premised on the internationalization of production and the ensuing complexity in the organizational structure of multinational enterprises (MNEs). This increased economicgeographical complexity, Friedmann (1986) argued, requires a limited number of control points in order to function, and world cities are deemed to be such points. Friedmann's observations quickly became the backbone for much research on the functional role of cities in an increasingly globalized economy. It provided the motivation for dozens of studies that sought to extend the theoretical framework (e.g. Sassen, 1991); to create methods for measuring world city-formation (e.g. Beaverstock et al., 2000); to explicitly test some of the assumptions in the mainstream conceptualizations (e.g. Hill \& Kim, 2000); and to provide in-depth insights through case studies of selected cities (e.g. Wang, 2003). Twenty years of research on world cities thus generated an enormous number of point of views (Brenner and Keil, 2006), meta-theoretical narratives (Saey, 2007) and methodological variations (Derudder, 2006), which makes it altogether impossible to speak of a coherent research paradigm. The blurry perimeter of this literature implies that some conceptual benchmarks need to be chosen when one aims to contribute to this literature. In this paper, we focus on the work of Saskia Sassen $(1991,2001,2002)$, who has undoubtedly become the major reference point in this research domain.

In her path-breaking book The Global City, Sassen (1991) looks afresh to the functional centrality of cities in the world economy, and she does so by focusing upon the attraction of business service firms (such as firms in accountancy, advertising, banking/finance, law, and management consultancy) to major cities that offer knowledge-rich and technology-enabled environments. In the 1980s and 1990s, many such service firms followed their global corporate clients to become important MNEs in their own right, albeit that these firms tend to be more susceptible to the agglomeration economies offered in city locations. The reason for this is to be found in the production process of these services, which involves a lot of face-to-face communication because of the necessity of multiple simultaneous inputs and feedbacks. Based on this insight, Sassen argues that the particular characteristics of the production process in these sectors explain the centralization of management and servicing functions that has fuelled the economic boom of the early and mid-1980s in a number of major cities across the globe ${ }^{2}$.

A major implication of Sassen's work is that the study of cities in the context of a globalizing economy should focus on "the practice of global control: the work of producing and reproducing the organization and management of a global production system and a global market-place for finance" (Sassen 1995, 63-64, her emphasis). Her theoretical framework can therefore be summarized as a continuously unfolding process in which territorial dispersal of production at a variety of scales raises demand for centrally produced internationalized business service firms in general and financial services in particular.

An operational definition of Sassen's widely acclaimed conceptualization of world city-formation has been provided by Beaverstock et al. (1999), who treat world cities as postindustrial production sites where innovations in corporate services and finance have been integral to

\footnotetext{
1 There are earlier uses of this term, but Brenner $(1998,5)$ notes that these uses reflected the "territorialization of the urbanization process on the national scale: the cosmopolitan character of world cities was interpreted as an expression of their host states' geopolitical power."

${ }^{2}$ Moreover, further concentration arises out of the needs and expectations of the people likely to be employed in these new high-skill jobs, and who tend to be attracted to the amenities and lifestyles that large urban centres can offer.
} 
contemporary globalization. World cities, therefore, are defined based on the presence of internationalized clusters of so-called 'advanced producer services' (APS) firms.

\section{Critique of the mainstream world city literature}

A major limitation of the research drawing on Sassen's conceptualization has been the disproportionate concentration on specific types of economic processes and relatively few large metropolitan centers to concomitant neglect of other processes and cities. This problem can, for instance, be observed in some of the empirical GaWC research that explicitly draws on Sassen's conceptual framework. A large number of GaWC's empirical analyses after the seminal Beaverstock et al. (1999) piece have been based on the corporate geographies of 100 'leading' business service firms, the so-called 'GaWC 100' (e.g, Taylor et al. 2002a,b; Derudder et al., 2003). The criterion for selecting the different firms was different for each of the APS sectors, as Taylor et al. (2002a) explain, but a common criterion was that each of the firms should have a presence in what they dub the 'three prime globalization arenas': northern America (the USA and Canada), Western Europe and Pacific Asia. This criterion has clearly resulted in a dataset with a very large presence of APS firms with Euro-American origins, so that some of the main conclusions in the GaWC studies regarding the perceived dominance of Western and Pacific Asian cities may well have been a self-fulfilling prophecy.

Beaverstock et al. (1999), for instance, looking through the lens of 'conventional' and 'advanced' business service firms, suggest that Istanbul is the only world city in the Greater MENA region, while seven other cities (i.e. Tel Aviv, Abu Dhabi, Cairo, Dubai, Riyadh, Tashkent, and Tehran) show 'evidence of world city formation' at best. The more recent and more detailed 'GaWC 100' study by Derudder et al. (2003), in turn, also features information on the (marginal) position of the likes of Doha, Amman, Tunis and Kuwait City, but still starts from the perspective how 'conventional' corporate service firms from the West make (a limited number of) connections to these MENA cities. As a consequence, and in spite of the relative geographical detail, such studies still fail to make conceptual linkages to other scales, regions and economic processes, which has led Stanley (2003) to the conclusion that there is a structural knowledge hole regarding the importance of MENA cities in terms of their functional role in globalized urbanization processes.

A number of researchers have discussed this particular limitation of the WCN literature at length (e.g. McCann, 2004), but the most trenchant critique along these lines has been by Robinson $(2002,536)$, who complains that "millions of people and hundreds of cities are dropped off the map of much research in urban studies." This exclusion is from two "maps': (i) the geographical map of world cities wherein most cities located in the 'Global South' are missing; and (ii) the conceptual map of world cities which focuses on a narrow range of economic processes (i.e. 'advanced' servicing of globalized production) so that myriad other connections between cities are missing. Underlying this critique is the idea that the WCN literature at large has largely failed to transcend its prime scale of interest, i.e. 'the global'. As Brown et al. (2008) have recently put it: world city studies need to address leading cities in the global economy to be sure, but there is no need to be ghettoized into a one-process and one-scale analysis, as the WCN is built upon ramifications of different operations across different scales (see Parnreiter, 2003). Thus, although recent GaWC attempts to analyse the WCN in greater geographical detail have extended our understanding beyond a limited number of leading cities, these studies have continued to focus on a specific kind of 'Western' economic processes, and have continued to fail explaining the connection to other scales and regions (Robinson, 2005).

Massey $(2007,34)$ has recently taken this criticism a step further, and urges us to consider additional implications of this neglect of an array of economic processes and a number of regions in Sassen's and GaWC's research. She suggests that use of the adjective 'advanced' when 
studying the urban geography of these largely Western business services firms implicitly grants these services (and the firms and the cities that provide them) a normative status in the sense that they implicitly suggest an inevitability of direction. She therefore calls for approaches that "expose the hegemonic geographical imaginations" and even "take the further political step of proposing alternatives" (Massey 2007, 24). The MENA region has been an obvious example of a victim of (and therefore possible alternative to) such hegemonic geographical imaginations. One way to put the region on the map is to shift our an analysis to the IFS sector, which has recently become a highly integrative force for the MENA region in and by itself, but also in terms of the linkages between this region end the rest of the world. The remainder of this paper is devoted to revealing this 'other' geography of contemporary WCN-formation.

\section{Islamic financial services: banking, finance and insurance}

The IFS sector provides a host of financial services based on Islamic religious grounds ${ }^{3}$. Perhaps the most important characteristic - and certainly the most widely known, for that matter - is the prohibition of raising interest in all its practices. In Islamic thought, time does not equal money. In other words: there is a strong belief that money should not make money by itself. For instance, in the case of a loan, a money lender has no right to earn money simply by lending it to the borrower. Rather, loans or investments are considered from a profit-and-loss sharing view: a money lender can get an extra return in the form of a pre-agreed part of the profits, or take the loss by ratio of the investment. In addition, other moral standards, such as the prohibition of uncertainty in contracts (gharar), gambling (maysir) and the consumption and production of certain forbidden (haram) products also regulate the functioning of IFS. More generally, IFS should be halal, meaning that they have to comply with the Shari'a, the highest Muslim Law.

The rise of IFS can be traced back to the 1973 energy crisis ${ }^{4}$, after which some of the oilproducing MENA states quickly accumulated enormous amounts of capital (see Tripp 2006, 104). This excess income was partly invested through 'conventional' banks throughout the world (but mainly headquartered in Europe and the United States), but it also resulted in the emergence of a number of new financial institutions and instruments within the region. Despite rather meagre results in absolute terms in the early years, the IFS sector has been rapidly expanding recently, with annual growth rates of $15 \%$ to $20 \%$. This success has undoubtedly been fuelled [sic] by a general 'Islamic revival', as Islamic banking and finance increasingly came to be regarded as the 'appropriate' way to do business for Muslims. The IFS sector now has an estimated worth of 500 billion US\$ (The Banker 2007, 10).

A large part of this recent growth has been due to the success of IFS beyond the MENA region. On the one hand, this globalization of the IFS sector has occurred through the emergence of new, full-fledged Islamic banks beyond the MENA (e.g., the 'Islamic Bank of Britain') or through the establishment of foreign branches of mainly Middle Eastern Islamic banks (e.g., Faisal Private Bank in Geneva, a subsidiary of the Manama-based Ithmaar Bank). On the other hand, product differentiation also occurred within (mostly) Western financial institutions that were already active in Muslim countries, either through branches or through the activities of affiliates. One obvious example includes conventional banks that have decided to offer Islamic products in Muslim markets through so-called Islamic 'windows' (e.g. HSBC through its subsidiary HSBC

\footnotetext{
${ }^{3}$ For a more detailed overview of the main features of the IFS sector, see e.g. Iqbal and Molyneux (2005).

${ }^{4}$ The Dubai Islamic bank, the first private interest-free bank, was set up in 1975 (Zaher and Hassan 2001, 169).
} 
Amanah, headquartered in London). Another example relates to Western banks such as Fortis Bank, Barclays, and Deutsche Bank that gained knowledge on Islamic banking and finance in Muslim countries, and started to introduce these gradually in non-Muslim countries. Fortis, for instance, relied on the IFS familiarity of its Malaysian affiliate Maybank for the introduction of its Shari'a compliant fund into the Belgian market in December 2007. In this paper, however, we are interested in the globalization of service provision from the MENA, and we therefore only focus on full-fledged IFS firms.

\section{Methodology}

In this paper, we draw on the methodology developed by Peter Taylor $(2001,2004)$ in conjunction with some of his GaWC colleagues for examining city network formation under conditions of contemporary globalization. The basic observation underlying Taylor's 'interlocking world city network' (IWCN) model is that cities are connected through partner offices of APS firms. Through the linkages generated by affiliated offices, vital strategic information/knowledge - needed for the coordination of its clients' business - flows between cities. Connections between cities are thus conceived as the aggregate of such corporate links, and WCN dynamics is therefore primarily an outcome of corporate location decisions by business service firms. Because this IWCN model is central to the research reported in this paper, we briefly summarize its main features.

As it is very difficult to measure the actual flows (e-mail traffic and telephone calls, mobility of employees, common projects among offices, reports, etc.) between offices located in different cities, Taylor (2001) starts from the measurement of the institutional structure in which those flows are created and travel around as a proxy for determining the connectivity among the constituent parts. In a first step, this implies recording the presence of a firm in a city, but also estimating the importance of this presence through a standardized 'service value' $v_{i j}$ measuring the importance of a city $i$ to the transnational network of a service firm $j$. The connectivity measures in the IWCN model are based on various usages of the latter value.

The first measure is the site service status $C_{a}$ of a city, which is simply the aggregation of the service value across all firms:

$C_{a}=\sum_{j} v_{a j}$

The actual evaluation of a city's connectivity is based on the calculation of a series of 'inter-lock relations' $r_{a b, j}$ between two cities $a$ and $b$ in terms of firm $j$. This relation can be computed based on the service values $v_{a, j}$ and $v_{b, j}$ for firm $j$ in both cities:

$r_{a b, j}=v_{a j .} v_{b j}$

The conjecture behind conceiving this product as a surrogate for actual flows of inter-firm information and knowledge is that the more important the office, the more connections there will be with other offices in a firm's network. This GaWC heuristic, which builds on the core ideas of spatial interaction modelling, seems reasonable when the following assumptions are made (see Derudder and Taylor 2005, 72-73). First, offices generate more flows within a firm's network than to other firms in their sector. This is inherently plausible in a context where protecting global brand image through providing seamless service is the norm. Second, the more important the 
office, the more flows are generated and these have a multiplicative effect on inter-city relations. The first part of this assumption is very plausible again. The second part reflects (i) the fact that larger offices with more practitioners have the capacity to create more potential dyads, and (ii) the hierarchical nature of office networks where larger offices have special functions like control and provision of specialised knowledge. The total connectivity $N_{a}$ of a city can be computed through aggregating these inter-city links $r_{a b, j}$ across all firms and all cities in the dataset:

$$
N_{a}=\sum_{b, j} r_{a b, j} \quad a \neq b
$$

For reasons of clarity, and to make this measure independent of the number of cities/firms in the dataset, $N_{a}$ is expressed as the proportion of the highest connectivity in the dataset (i.e., the city with the highest connectivity has a $N_{a}$ of 1 ).

Note that although the $C_{a}$ and $N_{a}$ rankings will obviously be interrelated (they are both based on the same input data), they are not necessarily the same. This is because they are based on different interpretations of the meaning of the presence of an APS office in a city. A city assuming a higher position in the $N_{a}$ ranking than in the $C_{a}$ ranking is relatively more connected to other cities, because firms with a presence in this city tend - on average - to be part of more extensive office networks. As a consequence, such a city may not boast a lot of APS offices, but tends to have offices of firms that have a substantial global presence.

\section{Data collection}

Following the specifications of the IWCN methodology data were required on the office networks of IFS firms that have 'gone global'. Data was collected in three steps. First, we gathered information on which firms are the main transnational players in the IFS sector. Second, we gained insight in the location strategies of these firms. And third, we standardized the multifarious information on these location strategies by summarizing it in a simple three-point scale.

In a first step, we identified the main transnational IFS firms in terms of asset value using 'The Banker's Top 500 Islamic Financial Institutions' publication (The Banker, 2007). From this list, we selected the top 100 full-fledged Islamic financial firms, thus discarding conventional banks with Islamic windows such as Citibank and HSBC as this would bias the results because of their extensive conventional branch network. The Shari'a compliant asset values of the selected IFS firms vary greatly. For example, number one ranked Melli, an Iranian bank, had an asset value of 35 billion US\$ in 2007. The top twelve firms have asset values above 10 billion US\$. The nature of the selected IFS firms is very diverse, and includes commercial and investment banks, government-owned banks and development banks, credit and finance institutions and insurance companies. Similar to the more commonly studies 'conventional' financial sector, IFS such as deposits, credit, finance, investment and insurance are increasingly interwoven and provided by one and the same financial institution. We therefore decided to map ISF without distinguishing between these specific activities.

Second, we collected information on the city-based location strategies of the top IFS firms. The data in The Banker's list only contains information on the country where the firms' headquarters are located. Following the data gathering strategy set in Taylor et al. (2002a), we searched the websites of each of the firms to get a hold of all relevant information regarding their city-centred 
location strategies, including information on the location of the head office, branches, subsidiaries, affiliates and representative offices (see Figure 1 ) $^{5}$. This analysis revealed that 28 out of the 100 leading IFS firms have established one or more offices in a city in another country, whereby a total of 64 cities are connected in the IFS city network in that they host one or more office of these 28 firms. It is the information on these 28 firms and 64 cities that we use in our ensuing analyses (see Table 1).

Figure 1 and Table 1 about here.

The third and last step involved compiling data on the importance of a given city to a firm's service provision, i.e. assigning the service values $v_{i j}$ for each city/firm-pair. As Taylor et al. (2002a) note, in conversion from website information to actual data there is always a tension between keeping as much of the original material as possible and creating a credible ordering that accommodates all degrees of information across cases. In their research framework, they used a six-point scale, which was reasonable given the broad range of extra-locational functions and firms sizes in the 'GaWC 100'. In our case, however, this turned out to be very complicated, mainly because of the difficulties involved in assessing the importance of the various offices. We therefore employed a simple, three-point scoring range: a service value of 0 obviously means that there was no office in a given city, a service value of 2 was given to the headquarter city, while a service value of 1 was given to all other offices (i.e. branches, subsidiaries, representative offices and affiliates) in the office network. The end result is obviously less than perfect, but it is the most credible way to describing the office networks of leading globalized IFS firms in 2007 in the absence of large-scale, readily available information on their location strategies.

\section{Results}

Applying the GaWC methodology summarized in equations (1) through (3), we derived measures of the cities' site service status $C_{a}$ and - drawing on the aggregated interlock links $r_{a b, j}$ across all firms - their total connectivity $N_{a}$. Table 2 presents an overview of the top-ranked cities in terms of total connectivity and site service status in the networks of the 28 transnational ISF firms, in addition to the number of headquarters of the 100 leading firms in terms of asset value. Figure 2, in turn, depicts an overview of the chief inter-city connections in the IFS city network. In this figure, the size of the nodes varies with the total connectivity $N_{a}$ of a city, while the size of the edges varies with the aggregated inter-lock relations $r_{a b}$. For reasons of clarity, only the most important nodes $\left(N_{a>0,20)}\right.$ and links $\left(r_{a b}>0,20\right)$ are shown.

Figure 2 and Table 2 about here.

Table 2 and Figure 2 provide a 'decentred' picture of contemporary WCN-formation. The basic outline of this IFS city network obviously differs from the WCN identified in GaWC research (which is summarized at length in Taylor, 2004): a lot of 'traditional' world cities are missing in this network, while new cities have appeared on the map. It is hereby clear that the MENA region at large forms the core of the IFS city network. The Gulf states in particular, which are the cradle of contemporary IFS ${ }^{4}$, host the best connected cities with Manama, Dubai and Abu Dhabi in the

\footnotetext{
${ }^{5}$ In the home country no other offices than the head office were considered, because we considered it as normal if e.g. an Iranian bank had 25 branch offices within the Iranian borders. We considered it to be far more important to map the presence of these institutions abroad to get insights in the transnational location behavior of these financial firms.
} 
top 10 in terms of total connectivity. In comparison to the Beaverstock et al. (1999) and Derudder et al. (2003) analyses, only Tel Aviv (unsurprisingly) disappears from the map.

Manama is the undisputed Mecca of the IFS sector: 7 out of 28 globalized IFS firms have their headquarters in Bahrain's capital. While Bahrain's attractiveness is generally understood in terms of its role as an offshore centre for 'mainstream' financial services, the fact that Manama is a crucial location for IFS firms can be explained through the presence of an array of organizations central to the development of Islamic finance, including the Accounting and Auditing Organization for Islamic Financial Institutions (AAOIFI), the Liquidity Management Centre (LMC), the International Islamic Financial Market (IIFM), and the Islamic International Rating Agency (IIRA) (Central Bank of Bahrain, 2008). Their presence gives Manama a competitive edge as innovation is crucial in this relatively new and quickly expanding sector. These observations are very much in line with Manama's status as a rising star in the world of financial centres more generally, as has recently been highlighted in The Global Financial Centres Index compiled by the City of London (2008).

Dubai is also well-connected in IFS office networks, albeit perhaps less so than could be expected based on its prominent role in other production networks. A certain degree of incompatibility between the Shari'a and the legal environment based on British common law (Caballo, 2007) may explain why the city is at present trailing Manama. Abu Dhabi takes on a somewhat peculiar position in that its relatively low site service status (3) is matched by a relatively high total connectivity $(0,36)$. While only 3 out of 28 transnational IFS firms have an office in Abu Dhabi (i.e. ABC Islamic Bank, Bank Melli and Iran Insurance Company), the city is well connected because these forms have an extensive international network. In other words: while Abu Dhabi hosts little transnational ISF firms and only one headquarter of such a firms, ISF firms having extensive transnational office networks tend to have a presence there.

On the Arabian Peninsula the Ras-al-Khaimah, Al Ain and Fujairah Emirates and Sana'a are well-connected nodes in IFS office networks. Near the Persian Gulf, Dammam and Doha are also well connected, but it is Tehran that dominates this region. Similar to Pakistan and Sudan, Iran has a fully 'Islamic economy', which was abruptly introduced between 1979 and 1982 after the Islamic revolution (Khan and Mirakhor 1990, 358-9). At this time, the entire Iranian banking system was nationalized and an unambiguous model of Islamic banking was adopted and implemented ${ }^{6}$. Out of the 20 biggest firms in this sector, 8 are headquartered in Tehran. In general, the Tehran-based firms have an extensive network both in Iran and abroad, with offices in the Middle East and Europe. This suggests that although the Iranian IFS were originally embedded in a strong national context, contemporary Tehran-based firms have an extensive border-crossing networked activity, particularly with London and Dubai.

Istanbul is also relatively well-connected, but much less so than could be expected based on it status in 'conventional' world city rankings. This confirms the observation that the Islamic financial sector is relatively small in Turkey as a whole (personal communication by Eric De Maeyer, Fortis Bank Project Manager on January 23 2008).

Karachi, as the largest city of another fully Islamic country, is also surprisingly weakly connected. This is because the intended islamization of the Pakistani banking and insurance sectors (and the economy as a whole) has been postponed. In practice, recent government action has been aimed at the development of a parallel Islamic banking and takaful sector alongside conventional banks and insurance companies (Bekkin 2007, 123-4). Furthermore, Karachi boasts a relatively low connectivity $(0,22)$ in comparison to its site service status (10) because the transnational IFS firms that have a presence there tend to have a limited network. Karachi is hereby particularly well-connected to cities in the Gulf. The office networks of two Pakistani banks, Bank Habib (with a presence in Karachi and Manama) and the National Investment Trust

\footnotetext{
${ }^{6}$ However, as Bekkin $(2007,124)$ has pointed out, the Iranian economy is not perfectly Islamic as it uses interest-based modes of finance (e.g. Eurobonds) as well.
} 
(with a presence in Karachi and Dubai) are indicative for the linkages between Pakistan and the Gulf states.

Other, less-connected cities in the Middle East are found in countries with relatively small Muslim populations, such as Yerevan and Baku. The urban geography of the ISF network also covers seven cities in North Africa, with Cairo and Tunis as cities boasting the highest connectivity. Rather than Casablanca, it is Rabat that connects Morocco to the international IFS network, harboring the regional headquarters of the Islamic Development Bank. Other connected cities are Alger, Dakar, Tripoli, and Khartoum. In spite of the fully Islamic character of the Sudanese economy, the latter city is surprisingly weakly connected: Khartoum is only linked in transnational IFS networks through the Al Baraka Banking Group. It should be noted, though, that 4 of the top 100 IFS firms have a headquarter presence in Khartoum, albeit they only have a national office network. In Somalia, in turn, the Al-Barakaat bank has been closed under the pressure of the Bush administration for their suspected financing of terrorist movements (see de Goede, 2003) ${ }^{7}$. In general, the African part of the IFS network closely follows Muslim presence. In Sub-Saharan Africa, only Durban is connected into the network, rather than the more commonly identified world cities Johannesburg and Cape Town.

Europe, North and South America, Oceania, and East Asia are less connected to the IFS city network. Particularly in the Americas, the usual suspects are being dropped off the map. Out of 40 cities identified in Beaverstock et al. (1999) as showing at least some evidence of world cityformation, only 4 are connected in the IFS city network, i.e. New York, Chicago, Atlanta, and Sao Paolo. The only new city that appears on the map is the offshore financial center Georgetown on the Cayman Islands.

In Europe, the situation is somewhat different. Although the number of cities is also heavily reduced (from 41 to 9), the remaining cities are relatively well-connected. This is especially the case for London and Paris. Apart from being a major centre for 'conventional' financial services, London appears to be the major hub for IFS firms outside the MENA region. Although it has only two IFS headquarters of the top 100 firms (i.e. the headquarters of the European Islamic Investment Bank and HSBC Amanah), the city ranks third in terms of site service status and total connectivity. This observation is in line with the intentions of the British government and Islamic finance stakeholders to make London the international centre of Islamic finance. As the chairman of the European Islamic Investment Bank (EIIB, 3, 7) recently declared:

"I am confident that we are uniquely positioned to benefit from London's position as the leading financial center in the world as the city positions itself as the global gateway for Islamic finance [...] We believe that the Bank's competitive positioning is significantly enhanced by its position in London, which is the pre-eminent global financial center with a robust and highly respected regulatory environment."

This observation is in tune with the observations of Faulconbridge (2004), who discusses why financial services remain embedded within 'International Financial Centres' (IFCs) when technology and myriad globalization processes would seem to facilitate de-concentration and geographical dispersion. As a leading IFC, London is accustomed to its dominant role in Europe, and its dominant position in IFS networks suggest some sort of anchoring of different types of financial services in the same location. Thus although the geography of the IFS city network is clearly different from the more commonly studied WCN and IFC system, it is clear that some sort of convergence is occurring as the IFS sector is also globalizing.

Furthermore, in Europe, the relation between the presence of a substantial Muslim population and the presence of IFS firms is obvious (but far from perfect). In the UK, for instance, the

\footnotetext{
${ }^{7}$ The impact on the Somalian economy has been quite dramatic, given the fact that the bank was a major channel of remittances from ex-pat Somalis.
} 
appearance of Bristol hints at the importance of IFS in the UK market more generally. Although the largest share (ca. 200 000) of the ca. 3 million Muslims lives in Berlin, Germany is represented by the service centers Frankfurt and Hamburg ${ }^{8}$, while Italy, with its estimated Muslim population of only 825000 (i.e. $1.4 \%$ of the total population) is connected through Rome and Milan. On the other hand, some countries with a very high percentage of Muslim population, such as Bosnia-Herzegovina (40\%), Albania (70\%), Macedonia (30\%), and Kosovo (90\%) have no national entry point into the IFS city network.

East Asian cities are also far less represented in the new archipelago. Kuala Lumpur appears to be the most-connected city, which may in part be traced back to some policies pursued by the Malaysian state, which provides substantial support to the IFS sector. Particularly in the field of insurance it has raised protective policies, such as tax breaks and other legal measures such as the Takaful Act of 1984 (Bekkin 2007, 127) Consequently, Kuala Lumpur has become a hot spot for ISF, with respectively 11 and 6 head offices of the top 100 IFS firms and the 28 international IFS firms. Most of these firm networks are however regional, linking Kuala Lumpur with Labuan and Jakarta, but also with some major cities in Gulf states, whereby Kuala Lumpur acts as a basing point for Middle Eastern IFS firms in the region (e.g. for the CIMB Islamic Bank Bd, which has a limited international presence in Kuala Lumpur, Bandar Seri Begawan and Manama). Kuala Lumpur's position in the IFS city network is therefore somewhat comparable to that of Karachi in that a relatively high site service status $(10)$ is not matched by a substantial connectivity $(0,32)$.

Other Asian cities such as Dhaka, Chittagong, Bandar Seri Begawan, and Labuan are also connected to the IFS network. However, perhaps the most remarkable feature here is the total absence of Tokyo. Whereas other international financial centers in the region such as Hong Kong and Singapore have at least some marginal connections to the network, Tokyo hosts at present no offices of fully-fledged IFS firms. This can perhaps be traced back to the fact that participation in the Japanese economy still means going through a lot of government channels given a fairly regulated economy.

\section{Conclusions}

The overall objective of this paper can be cast in two different forms. First, from the perspective of cities as providers of (corporate) services, we investigated the specific ways in which IFS are being provided throughout the world. Second, from the perspective of WCN research, we have investigated the way in which some poorly connected regions such as the MENA nonetheless produce/obtain specific, but increasingly substantial amounts of globalized financial services. By putting agency into the hands of non-Western financial agents, we hope to have aided in 'decentering' some of the overriding geographic imaginations (see Pollard and Samers, 2007), and move away from the problematic dominance of a limited number of economic processes and cities in this research domain (see Robinson, 2002, 2005; McCann, 2004; Massey, 2007).

The major findings of this analysis can be summarized as follows. First, while cities in the Islamic world are in general well-connected by IFS firms, it is Middle Eastern cities such as Manama, Tehran, Dubai, Beirut, Amman, and Abu Dhabi that are leading the way. Manama is the major IFS hub within the MENA region, but Tehran and Dubai also play an instrumental role in the integration of the MENA region into the global economy, and this mainly through their

8 All figures regarding Muslim populations in European countries are based on http://news.bbc.co.uk/2/hi/europe/4385768.stm, accessed May 28, 2008. 
strong links with London. Second, some key cities outside the Muslim world appear to becoming hot spots for the provision of IFS. London and - albeit to a lesser extent - Paris are the major examples here, which leads to the more general suggestion that the globalizing IFS sector is becoming anchored in the more conventional world cities and IFCs (cf. also the connectivity of Georgetown on the Cayman Islands and the importance of Manama as an IFC in more general terms). In this context, it seems likely that IFS institutions equally benefit from the agglomeration economies identified by Sassen (1991), so that positive spill-over effects between the Islamic and the conventional financial sector are likely. However, more research is needed to understand why IFS presence in these traditional IFCs is becoming crucial. However, and third, this gradual anchoring of the IFS sector in major world cities does not result in a carbon copy of the traditional IFC-system and the WCN identified in Taylor (2004). Indeed, a number of 'usual suspects' in the global financial system are only marginally connected (e.g., New York, Frankfurt, and Singapore) or even missing (e.g. Tokyo) in the transnational city networks generated by IFS firms.

\section{References}

Beaverstock J V, Smith R G and Taylor P J 1999 A roster of world cities Cities 16 (6) 445-458

Beaverstock J V, Smith R G, Taylor P J, Walker D R F and Lorimer H 2000 Globalization and world cities: some measurement methodologies Applied Geography 20 (1) 43-63

Bekkin R I 2007 Islamic insurance: National features and legal regulation Arab Law Quarterly 21 (2) 109-134

Borgatti S P, Everett M G and Freeman L C 2002 Ucinet for Windows: Software for social network analysis Analytic Technologies, Harvard

Brenner N 1998 Global cities, glocal states: global city formation and state territorial restructuring in contemporary Europe Review of International Political Economy 5 (1) 1-37

Brenner N and Keil R eds 2006 The Global Cities Reader Routledge, London

Brown E, Catalano G and Taylor P J 2002 Beyond world cities: Central America in a global space of flows Area 34 (2) 139-148

Brown E, Derudder B, Parnreiter C, Pelupessy W, Taylor P J and Witlox F 2008 World city networks and global commodity chains: Towards a world-systems' integration GaWC Research Bulletin 236 (http://www.lboro.ac.uk/gawc/rb/rb236.html) under review

Caballo A 2007 The law of the Dubai International Financial Centre: Common law oasis or mirage within the UAE? Arab Law Quarterly 21 (1) 91-104

Central Bank of Bahrain 2008 Islamic finance (http://www.cbb.gov.bh) Accessed 1 September

City of London 2008 The Global Financial Centers Index 2008 (http://www.cityoflondon.gov.uk/Corporation/) Accessed 5 September

de Goede M 2003 Hawala discourses and the war on terrorist finance Environment and Planning D: Society and Space 21 513-532

Derudder B, Taylor P J, Witlox F and Catalano G 2003 Hierarchical tendencies and regional patterns in the world city network: A global urban analysis of 234 cities Regional Studies 37 (9) 875-886

Derudder B and Taylor P J 2005 The cliquishness of world cities Global Networks - A journal of transnational affairs 5(1) 71-91

Derudder B 2006 On conceptual confusion in empirical analyses of a transnational urban network Urban Studies 43 (11) 2027-2046

European Islamic Investment Bank 2008 Annual report \& Accounts 2006 (http://www.eiib.co.uk/html/index.asp) Accessed 7 April

Faulconbridge J R 2004 London and Frankfurt in Europe's evolving financial centre network Area 36 (3) 235-244 
Friedmann J 1986 The world city hypothesis Development and Change 17 (1) 69-83

Friedmann J and Wolff G 1982 World city formation: an agenda for research and action International journal of urban and regional research 6 (3) 309-344

Hill R C and Kim J 2000 Global cities and developmental states New York, Tokyo, and Seoul Urban Studies 37 (12) 2167-2195

Iqbal M and Molyneux P 2005 Thirty years of Islamic banking: History, performance and prospects Palgrave Macmillan, New York

Khan M S and Mirakhor A 1990 Islamic Banking: Experiences in the Islamic Republic of Iran and Pakistan. Economic Development and Cultural Change 38 (2) 353-375

McCann E 2004 Urban political economy beyond the 'global' city Urban Studies 41 (12) 23152333

Massey D 2007 World City Polity Press, Cambridge

Parnreiter C 2003 Global City Formation in Latin America: Socioeconomic and Spatial Transformations in Mexico City and Santiago de Chile GaWC Research Bulletin 103 (http://www.lboro.ac.uk/gawc/rb/rb103.html)

Pollard J and Samers M 2007 Islamic banking and finance: postcolonial political economy and the decentring of economic geography Transactions of the Institute of British Geographers 32 (3) 313-330

Robinson J 2002 Global and World Cities: A View from off the Map International Journal of Urban and Regional Research 26 (3) 531-554

Robinson J 2005 Urban geography: world cities, or a world of cities Progress in Human Geography 29 (6) 757-765

Saey P 2007 How cities scientifically (do not) exist: Methodological appraisal of research on globalizing processes of intercity networking in Taylor P J, Derudder B, Saey P and Witlox F eds Cities in globalization: Practices, policies and theories Routledge, London and New York 298-313

Sassen S 1991 The global city: New York, London, Tokyo Princeton University Press, Princeton

Sassen S 1995 On concentration and centrality in the global city in Knox P L and Taylor P J eds World cities in a world-system Cambridge University Press, Cambridge, 63-78.

Sassen S 2001 The global city: New York, London, Tokyo (2nd edition) Princeton University Press, Princeton

Sassen S ed 2002 Global Networks, Linked Cities Routledge, New York

Stanley B 2003 'Going global' and wannabe world cities: (Re)conceptualizing regionalism in the Middle East in Dunaway WA ed Emerging issues in the $21^{\text {st }}$ century world-system Vol I Crisis and resistance in the $21^{\text {st }}$ century world-system Praeger, Westport 151-70

Taylor P J 2001 Specification of the world city network Geographical Analysis 33(2) 181-194

Taylor P J, Catalano G and Walker D R F 2002a Measurement of the world city network Urban Studies 39 2367-2376

Taylor P J, Catalano G and Walker D R F 2002b Exploratory analysis of the world city network Urban Studies 39 2377-2394

Taylor P J 2004 World city network: A global urban analysis Routledge, London and New York

The Banker 2007 Top 500 Islamic Financial Institutions November supplement

Tripp C 2006 Islam and the moral economy: The challenge of capitalism Cambridge University Press, Cambridge

Wang C H 2003 Taipei as a global city: A theoretical and empirical examination Urban Studies 40 (2) 309-334

Zaher T S and Hassan M K 2001 A comparative literature survey of Islamic finance and banking Financial Markets, Institutions \& Instruments 5 (4) 155-199 


\section{Figures and Tables}

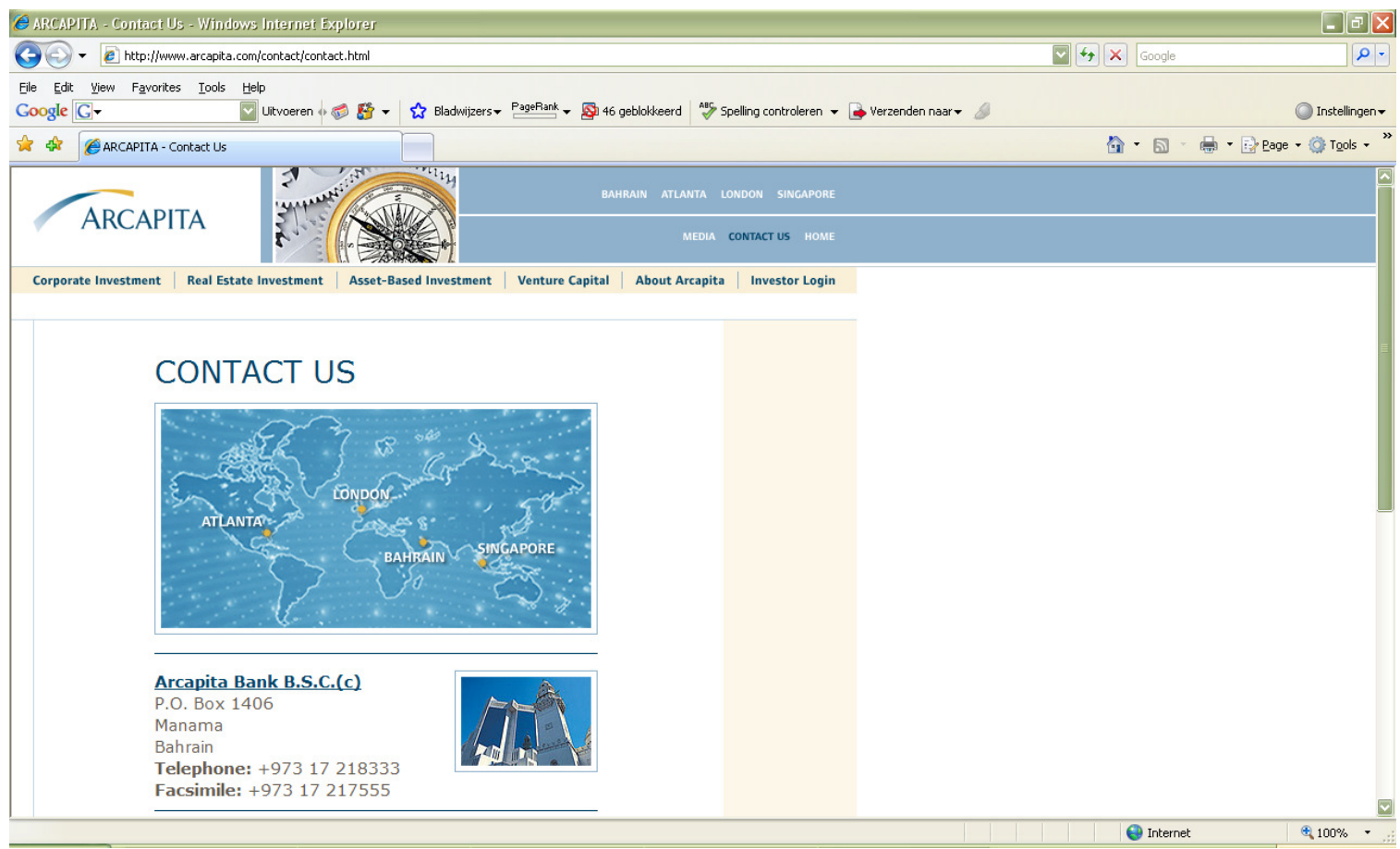

Figure 1: Website searches of IFS firms are used to get hold of all relevant information regarding their city-centred location strategies.

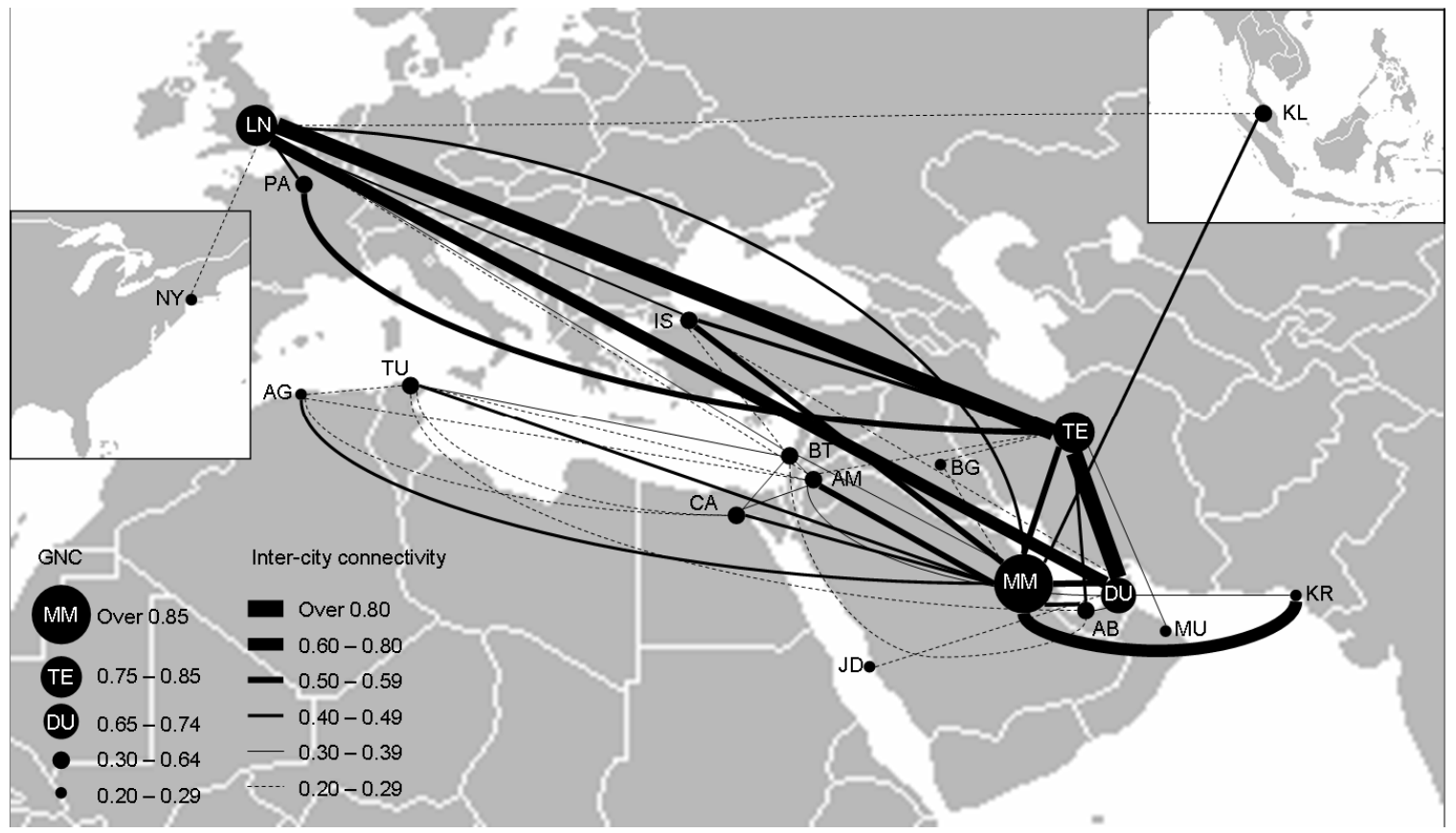

Figure 2: Major inter-city relations in the IFS city network*. 
*: The size of the nodes varies with the total connectivity $N_{a}$ of a city, while the size of the edges varies with the aggregated inter-lock relations $r_{a b}$. For reasons of clarity, only the most important nodes $\left(N_{a>0,20)}\right.$ and links $\left(r_{a b}>0,20\right)$ are shown.

Table 1: Leading IFS firms in terms of asset value (based on The Banker, 2007). Only firms with a transnational presence are listed.

\begin{tabular}{|c|c|}
\hline Islamic Financial Institution & Shari'a compliant assets (in million US\$) \\
\hline Bank Melli Iran & $35,493.32$ \\
Bank Mellat & $25,128.62$ \\
Kuwait Finance House & $21,836.22$ \\
Bank Tejarat & $18,945.38$ \\
Dubai Islamic Bank & $17,544.98$ \\
Blom Bank & $14,219.78$ \\
Bank Sepah & $13,913.53$ \\
HSBC Amanah & $9,725.00$ \\
Al Baraka Banking Group & $7,625.83$ \\
Bank Alfalah & $4,525.50$ \\
Qatar Islamic Bank & $4,090.25$ \\
ABC Islamic Bank & $3,484.00$ \\
Ithmaar Bank BSC & $3,179.94$ \\
Arcapita Bank BSC & $2,707.71$ \\
Bank Al Habib Lmt & $2,024.02$ \\
Shamil Bank & $1,693.26$ \\
Iran Insurance Company & $1,515.98$ \\
Karafarin Bank & $1,387.38$ \\
National Investment Trust & $1,248.40$ \\
Syarikat Takaful Malaysia Bhd & 825.82 \\
CIMB Islamic Bank Bd & 712.52 \\
Islamic Development Bank & 680.43 \\
Al Baraka Islamic Investment Bank & 559.66 \\
European Islamic Investment Bank & 463.82 \\
Islamic Arab Insurance Co.-Salama & 375.39 \\
Unicorn Investment Bank BSC & 293.34 \\
B.E.S.T. Retakaful & 279.88 \\
International Investment Group & 269.44 \\
\hline
\end{tabular}


Table 2: Top-ranked cities in the IFS city network in terms of total connectivity, site service status and number of head offices.

\begin{tabular}{|c|c|c|c|c|}
\hline $\begin{array}{c}\text { Total } \\
\text { Connectivity } \\
\text { Rank }\end{array}$ & City & $\begin{array}{c}\text { Total } \\
\text { Connectivity }\end{array}$ & $\begin{array}{l}\text { Site Service } \\
\quad \text { Status }\end{array}$ & \# of head offices \\
\hline 1 & Manama & 1,00 & 23 & 15 \\
\hline 2 & Tehran & 0,84 & 14 & 12 \\
\hline 3 & London & 0,78 & 13 & 2 \\
\hline 4 & Dubai & 0,68 & 12 & 5 \\
\hline 5 & Amman & 0,45 & 5 & 2 \\
\hline 6 & Beirut & 0,44 & 6 & 1 \\
\hline 7 & Paris & 0,42 & 5 & 0 \\
\hline 8 & Istanbul & 0,38 & 6 & 3 \\
\hline 9 & Abu Dhabi & 0,36 & 3 & 1 \\
\hline 10 & Cairo & 0,35 & 4 & 2 \\
\hline 11 & Tunis & 0,34 & 5 & 1 \\
\hline 12 & Kuala Lumpur & 0,32 & 10 & 10 \\
\hline 13 & Alger & 0,26 & 4 & 1 \\
\hline 14 & Baghdad & 0,26 & 2 & 0 \\
\hline 15 & Jeddah & 0,23 & 4 & 2 \\
\hline 16 & Al Ain & 0,22 & 2 & 0 \\
\hline 17 & Karachi & 0,22 & 10 & 6 \\
\hline 18 & Muscat & 0,22 & 2 & 0 \\
\hline 19 & $\begin{array}{l}\text { Ras-Al- } \\
\text { Khaimah }\end{array}$ & 0,22 & 2 & 0 \\
\hline 20 & New York & 0,21 & 2 & 0 \\
\hline
\end{tabular}

